\title{
Effects of Eurya japonica extracts on human corneal epithelial cells and experimental dry eye
}

\author{
LAN LI $^{1,2}$, RUJUN JIN ${ }^{1}$, YING LI ${ }^{1}$, JONG HYUN NHO ${ }^{3}$, WON CHOI ${ }^{1}$, \\ YONG SOK JI ${ }^{1}$, HYEON JEONG YOON ${ }^{1}$ and KYUNG CHUL YOON ${ }^{1}$
}

\begin{abstract}
Departments of ${ }^{1}$ Ophthalmology and ${ }^{2}$ Biomedical Sciences and Center for Creative Biomedical Scientists, Chonnam National University Medical School and Hospital, Gwangju 61469; ${ }^{3}$ Department of Korean Medicine Preclinical

Trial Center, National Development Institute of Korean Medicine, Jangheung-gun 59319, Republic of Korea
\end{abstract}

Received August 12, 2019; Accepted February 28, 2020

DOI: $10.3892 /$ etm.2020.8830

\begin{abstract}
Eurya japonica (EJ) leaves have been indicated to exert anti-oxidative and anti-inflammatory effects. Dry eye disease (DED) is a chronic inflammatory disease and oxidative stress is closely associated with DED. The aim of the present study was to analyze the therapeutic efficacy of EJ in DED using human corneal epithelial (HCE) cells and a mouse model of experimental dry eye (EDE). EJ extracts $(0.001$, 0.01 and $0.1 \%$ ) were used to treat HCE cells. Cell viability and mitochondrial function were detected using a EZ-Cytox cell viability assay kit and mitochondrial membrane potential assays. Dichlorofluorescein diacetate (DCF-DA) assay was used to measure cellular reactive oxygen species (ROS) levels. Subsequently, eye drops consisting of BSS or $0.001 \%, 0.01$ and $0.1 \%$ EJ extracts were applied for treatment of EDE. At 7 days, conjunctival ROS production was measured using a DCF-DA assay. Tumor necrosis factor (TNF)- $\alpha$, interleukin (IL)-1 $\beta$, $10 \mathrm{kDa}$ interferon gamma-induced protein 10 (IP-10) and monokine induced by interferon- $\gamma$ (MIG) levels in the conjunctiva were analyzed using a multiplex immunobead assay. Tear film and ocular surface parameters were measured. Treatment with EJ extracts in HCE cells effectively improved cell viability, ROS levels and mitochondrial function. Mice treated with 0.01 and $0.1 \%$ EJ extracts indicated a significant decrease in ROS, TNF- $\alpha$, IL-1 $\beta$, IP-10 and MIG levels compared with the EDE or BSS groups. Furthermore, a significant improvement in all clinical parameters was observed in the 0.01 and $0.1 \%$ EJ extract groups. EJ extracts could decrease cytotoxicity and ROS production in HCE cells. Additionally, topical EJ extracts reduced oxidative damage and inflammation and improved
\end{abstract}

Correspondence to: Professor Kyung Chul Yoon, Department of Ophthalmology, Chonnam National University Medical School and Hospital, 42 Jebong-ro, Dong, Gwangju 61469, Republic of Korea E-mail: kcyoon@jnu.ac.kr

Key words: corneal epithelial cells, Eurya japonica, dry eye, inflammation, oxidative stress clinical signs of EDE, suggesting that EJ extracts may be used as an adjunctive therapy for DED.

\section{Introduction}

Dry eye (DE) is a chronic inflammatory disease caused by a lack of or excessive evaporation of tears, which causes damage to the interpalpebral ocular surface and is associated with symptoms of ocular discomfort (1). DE affects $\sim 14.5 \%$ of the world's population, with rising prevalence (2). In the developed world, DE has become one of the leading reasons for patients seeking ophthalmological care (3). Currently, cyclosporine and artificial tears have been the main treatment approaches for chronic inflammatory DE $(4,5)$. However, to the best of our knowledge, the pathogenesis of DE has not been fully elucidated.

Oxidative stress and increased levels of reactive oxygen species (ROS) are known to serve important roles in the development of DE (6). The close relationship between lipid peroxidation-related membrane injury, protein oxidation, ROS production and inflammation was confirmed in patients and animal models of DE (7-9). Previous studies have demonstrated that topically applied medicinal plant extracts or tropical tree leaf extracts are effective for stressed human corneal epithelial (HCE) cells and murine DE by exhibiting anti-oxidative and anti-inflammatory properties (10-12). Furthermore, anti-oxidative glasses containing extracts of medicinal plants were also indicated to be effective in improving symptoms of $\mathrm{DE}$, both reducing dryness and redness and increasing tear break up time (TBUT) and Schirmer's test results (13).

Eurya japonica (EJ) is an ornamental plant distributed in coastal areas, particularly in southern Korea, southern China and south central Japan $(14,15)$. The leaves of Eurya emarginata have been used to treat ulcers or as a diuretic in certain regions of Asia (14). Recent studies have suggested that EJ has a variety of biological functions, including anti-cytotoxic, anti-apoptotic, anti-angiogenic and anti-cancer effects (14,16-19). Furthermore, chrysoeriol, eutigoside B and eutigoside $\mathrm{C}$ isolated from $\mathrm{EJ}$ leaves were revealed to exert anti-oxidative and anti-inflammatory effects (19-21). However, to the best of our knowledge, no studies have investigated the effectiveness of EJ in the treatment of inflammatory ocular diseases. 
Based on the aforementioned characteristics of EJ, it was hypothesized that EJ extracts may exhibit an effect on DE-associated inflammation and oxidative damage. Therefore, the efficacy of topical EJ extracts in HCE cells and murine experimental dry eye (EDE) was investigated.

\section{Materials and methods}

Preparation of EJ leaf extracts. EJ leaves were collected from the Jangseong province of South Korea. Following collection, fresh leaves were washed with distilled water and placed in a drying oven set to $40^{\circ} \mathrm{C}$. After 10 days, when the water content of the leaves was $<5 \%$ of their dry weight, the leaves were grinded to a size of $0.5 \mathrm{~mm}$ using a pin-type mill. The samples were extracted using a supercritical $\mathrm{CO}_{2}$ extraction system (cat. no. 06RA06-104010-A0031; ISA-SCFE system; Ilshin Autoclave Co., Ltd) at the Nano Bio Research Center, Jangseong. Pure $\mathrm{CO}_{2}$ was applied to the samples using a syringe pump. Each container was filled with leaves weighing 100-125 g, and under a pressure of 200 bar, $\mathrm{CO}_{2}$ was used as the main extraction gas, $\mathrm{C}_{2} \mathrm{H}_{3} \mathrm{OH}$ was used as the co-solvent and supercritical extraction was performed $(22,23)$. During the $2 \mathrm{~h}$ extraction process, care was taken to control the temperature, pressure and $\mathrm{CO}_{2}$ flow at $40^{\circ} \mathrm{C}, 200$ bar and $60 \mathrm{ml} / \mathrm{min}$, respectively, and the co-solvent flow rate was $3 \mathrm{ml} / \mathrm{min}$. EJ extract concentrations with a density of $0.818 \mathrm{~g} / \mathrm{ml}$ were collected by supercritical fluid extraction at $40^{\circ} \mathrm{C}$ for $120 \mathrm{~min}$ and stored in a clean vial at $-20^{\circ} \mathrm{C}$ until subsequent use.

EJ extracts were diluted to concentrations of $0.001,0.01$ and $0.1 \%$ for both in vitro and in vivo experiments. For in vitro experiments, EJ extracts were diluted with phosphate-buffered saline (PBS; Biosesang). For animal experiments, EJ extracts were diluted with balanced salt solution (BSS; Alcon).

Cell culture and viability assay. HCE-2 [50.B1] cells (cat. no. CRL-11135; American Type Culture Collection) at passage 28 were cultured at $37^{\circ} \mathrm{C}$ in a humidified incubator containing $5 \% \mathrm{CO}_{2}$. Cells were maintained in EpiLife ${ }^{\circledR}$ (Gibco; Thermo Fisher Scientific, Inc.) medium and supplemented with human corneal growth supplement (1X; Gibco; Thermo Fisher Scientific, Inc.), $100 \mathrm{U} / \mathrm{ml}$ penicillin and $100 \mu \mathrm{g} / \mathrm{ml}$ streptomycin (Gibco; Thermo Fisher Scientific, Inc.).

Cell viability was measured using a water-soluble tetrazolium salt (WST)-based EZ-Cytox assay kit (DoGen Bio Co., Ltd.) (24). HCE cells ( $2 \times 10^{5}$ cells/well) were seeded in a 96 -well plate and incubated for $24 \mathrm{~h}$ at $37^{\circ} \mathrm{C}$. Subsequently, the cells were pre-treated with different concentrations of $\mathrm{EJ}$ extracts (0.001, 0.01 and $0.1 \%$ diluted in PBS) and PBS only for $1 \mathrm{~h}$ at $37^{\circ} \mathrm{C}$. PBS only-treated cells were used as a negative control. Cells were then rinsed with PBS and cultured for an additional $24 \mathrm{~h}$ at $37^{\circ} \mathrm{C}$. Plates containing $10 \mu \mathrm{l}$ WST (DoGen Bio Co., Ltd.) reagent solution in each well were incubated at $37^{\circ} \mathrm{C}$ for an additional $3 \mathrm{~h}$ in a $\mathrm{CO}_{2}$ incubator. The absorbance was measured at a wavelength of $570 \mathrm{~nm}$ using an ELx808 absorbance microplate reader (BioTek Instruments, Inc.). Cells treated with $200 \mu \mathrm{M}$ hydrogen peroxide $\left(\mathrm{H}_{2} \mathrm{O}_{2}\right.$; Thermo Fisher Scientific, Inc.) were used as a positive control to evaluate the effect of the EJ extracts on cell viability following oxidative stress (25). To maximize the antioxidative effects of EJ extracts, EJ extracts were diluted to several different concentrations (0.001, 0.01 and $0.1 \%$ ) with PBS. Cells were pretreated with PBS only, 0.001, 0.01 or $0.1 \% \mathrm{EJ}$ extracts for $1 \mathrm{~h}$ at room temperature, followed by treatment with $200 \mu \mathrm{M} \mathrm{H}_{2} \mathrm{O}_{2}$ at room temperature for 30 min. In addition, cells untreated with EJ extract or $\mathrm{H}_{2} \mathrm{O}_{2}$ were used as a negative control. EJ extract-pre-treated and $\mathrm{H}_{2} \mathrm{O}_{2}$-treated cells were used for subsequent in vitro assays. Each assay was performed in triplicate.

Determination of intracellular ROS levels. The levels of intracellular ROS were determined using the CM-H2DCFDA kit (cat. no. C6827; Invitrogen; Thermo Fisher Scientific, Inc.) according to the manufacturer's protocols, as previously described (11). Briefly, HCE cells were washed three times with PBS, cells were seeded in PBS containing $10 \mu \mathrm{M}$ chloromethyl- $\mathrm{H}_{2} \mathrm{DCF}-\mathrm{DA}$ for $30 \mathrm{~min}$ at $37^{\circ} \mathrm{C}$ and washed another three times with PBS. Cellular fluorescence was quantified using a fluorescent microscope (magnification, x40; Eclipse TE300; Nikon Corporation) at an excitation setting of $515 \mathrm{~nm}$ and an emission setting of $550 \mathrm{~nm}$. Dichlorodihydrofluorescein diacetate (DCF-DA) fluorescence intensities were quantified using ImageJ software (version 1.45; National Institutes of Health) and expressed as percentages normalized to the negative control.

Mitochondrial membrane potential assay. To determine whether EJ extracts alter the mitochondrial function in cells under $\mathrm{H}_{2} \mathrm{O}_{2}$-induced oxidative stress, a 5,5',6,6'-tetrachloro-1,1',3,3'-tetraethyl benzimidazolylcarbocyanine iodide (JC-1) probe was used to assess the loss of mitochondrial membrane potential (26). EJ extract-pre-treated and $\mathrm{H}_{2} \mathrm{O}_{2}$-treated cells were cultured at $37^{\circ} \mathrm{C}$ on 6 -well culture plates at a concentration of $1 \times 10^{5}$ cells per well and incubated with $2 \mu \mathrm{M}$ JC-1 (Invitrogen; Thermo Fisher Scientific, Inc.) for $30 \mathrm{~min}$ at $37^{\circ} \mathrm{C}$. Cells were washed with PBS and incubated with $1 \mathrm{ml} \mathrm{Accutase}{ }^{\circledR}$ solution (cat. no. A1110501; Thermo Fisher Scientific, Inc) at $37^{\circ} \mathrm{C}$ for flow cytometry analysis. The plates were carefully tapped to detach the cells after 2 min of incubation. Suspended cells were then washed twice with cold PBS and resuspended in cold PBS. Flow cytometer (BD Accuri C6; BD Biosciences) and the flow cytometric analysis program (BD Accuri C6 Software; version 202.8; BD Biosciences) were used to quantify JC-1 fluorescence; a decrease in red fluorescence $\left(\mathrm{F}_{2585}\right)$ accompanied by an increase in green fluorescence $\left(\mathrm{F}_{2510}\right)$ indicated a decrease in the mitochondrial membrane potential. Red fluorescence was calculated relative to the percentage of the total fluorescence (summation of red and green fluorescence).

Mouse model of dry eye and experimental design. The research protocol was approved by the Chonnam National University Medical School Research Institutional Animal Care and Use Committee (approval no. CNU IACUC-H-2015-11). Maintenance of animals and all in vivo experiments were performed in accordance with the Association for Research in Vision and Ophthalmology statement for the Use of Animals in Ophthalmic and Vision Research.

Female C57BL/6 mice (age, 6-8 weeks; weight, 16.0 2 g; $\mathrm{n}=25$ ) were obtained from Orient Bio Center and used 
following experiments. The EDE mouse model was induced via subcutaneous injection of $0.5 \mathrm{mg} / 0.2 \mathrm{ml}$ scopolamine hydrobromide (Sigma-Aldrich; Merck KGaA) four times per day (at 8 and 11 am and 2 and $5 \mathrm{pm}$ ) with exposure to an air draft and $30 \%$ ambient humidity for seven days, as previously described $(27,28)$. During the experiments, animal movement and food and water intake were not restricted. The animals were housed at $22^{\circ} \mathrm{C}$ and $30 \%$ humidity on a $12 \mathrm{~h}$ light/dark cycle.

The mice were randomly assigned to five groups based on the topical treatment, which was administered for seven days, as follows: i) EDE control mice that received no eye drops; ii) EDE mice treated with BSS (Alcon); iii) EDE mice treated with $0.001 \%$ EJ extract (Nano Bio Research Center); iv) EDE mice treated with $0.01 \%$ EJ extract (Nano Bio Research Center) and v) EDE mice treated with $0.1 \%$ EJ extract (Nano Bio Research Center). EJ extracts were diluted in BSS for each treatment group. A total of $2 \mu 1$ eye drops (BSS; 0.001 ; 0.01 or $0.1 \%$ EJ extract) were applied topically to both eyes of the mice three times a day for seven days. Clinical parameters, including tear volume, tear film break-up time and corneal fluorescein staining scores (CFSS) (29) were measured on the seventh day of treatment. Measurements were made $3 \mathrm{~h}$ following the last scopolamine injection and eye drop application. After measurement of the clinical parameters, the mice were anesthetized via intraperitoneal injection of sodium pentobarbital $(50 \mathrm{mg} / \mathrm{kg})$. Transcardial perfusion was then performed with phosphate buffer $(\mathrm{pH} 7.4)$ for euthanasia. A multiplex immunobead assay and measurement of conjunctival ROS production using a CM-H2DCFDA kit were performed following tissue harvesting. Each group consisted of five mice. All experiments and analyses were repeated three times.

Measurement of cellular ROS levels. Levels of intracellular ROS production were measured using a CM-H2DCFDA kit according to the manufacturer's protocol, as previously described (12). In summary, the conjunctivas of the mice (5 eyes/group) were surgically harvested, dipped in PBS, torn apart using scissors and incubated at $37^{\circ} \mathrm{C}$ for $1 \mathrm{~h}$ in the presence of $0.5 \mathrm{mg} / \mathrm{ml}$ collagenase type D (Roche Applied Science). Following incubation, the tissues were disrupted by grinding using a syringe plunger and passed through a cell strainer with a pore size of $100 \mathrm{~mm}$. Cells were centrifuged at $450 \mathrm{x} \mathrm{g}$ for $7 \mathrm{~min}$ at $4^{\circ} \mathrm{C}$ and washed with PBS and $10 \mu \mathrm{M}$ DCF-DA (cat. no. D399; Molecular Probes; Thermo Fisher Scientific, Inc.) and incubated for $30 \mathrm{~min}$ at $37^{\circ} \mathrm{C}$. Cells were analyzed using a FACSCalibur flow cytometer (BD Biosciences) at an excitation wavelength of $480 \mathrm{~nm}$ and an emission wavelength of $530 \mathrm{~nm}$. The results were expressed as the mean percentage increase of DCF-DA fluorescence over the control tissue (conjunctival tissue harvested from mice that were not exposed to desiccant stress or topical treatment) with CellQuest software (version 5.2.1; BD Biosciences).

Multiplex immunobead assay for inflammatory cytokines and chemokines. A multiplex immunobead assay (cat. no. LX200-XPON3.1; Luminex 200; Luminex Corporation) was used to measure the concentrations of tumor necrosis factor (TNF)- $\alpha$, interleukin (IL)-1 $\beta, 10 \mathrm{kDa}$ interferon gamma-induced protein 10 (IP-10) and monokine induced by interferon- $\gamma$ (MIG) in the conjunctivas, as previously described (30). Conjunctival tissues were collected (five eyes per group) and pooled in a lysis buffer (TissueLyser; Qiagen $\mathrm{GmbH}$ ) containing protease inhibitor for $30 \mathrm{~min}$. Cell extracts were then centrifuged at $14,000 \mathrm{x} \mathrm{g}$ at $4^{\circ} \mathrm{C}$ for $15 \mathrm{~min}$. The supernatants were stored at $-70^{\circ} \mathrm{C}$ until further analysis. After centrifugation, each sample $(10 \mu \mathrm{g} / 25 \mu \mathrm{l})$ was added to a well of a 96-well plate and incubated in the dark overnight at $4^{\circ} \mathrm{C}$ with $25 \mu \mathrm{l}$ of $1 \mathrm{X}$ beads conjugated to the following mouse cytokine/chemokine-specific antibodies: Anti-mouse TNF- $\alpha$ (cat. no. MCYTNFA-MAG; Milliplex ${ }^{\circledR}$; Merck KGaA), anti-mouse IL-1 $\beta$ (cat. no. MIL1B-MAG; Milliplex ${ }^{\circledR}$; Merck KGaA), anti-mouse IP-10 (cat. no. MIP10-MAG; Milliplex ${ }^{\circledR}$; Merck KGaA), anti-mouse MIG (cat. no. MMIG-MAG; Milliplex ${ }^{\circledR}$; Merck KGaA). Serial dilutions of each cytokine/chemokine (cat. no. MTH17-8047; Milliplex ${ }^{\circledR}$; Merck KGaA) were also added to wells in the same plate to generate a standard curve. The next day, the beads were washed with wash buffer (cat. no. L-WB; Milliplex ${ }^{\circledR}$; Merck KGaA) and mixed with $25 \mu \mathrm{l}$ of $1 \mathrm{X}$ biotinylated secondary cytokine/chemokine antibody mixture (cat. no. MTH17-1047; Milliplex ${ }^{\circledR}$; Merck KGaA) for $1 \mathrm{~h}$ at room temperature, followed by washing with wash buffer and subsequent incubation with $25 \mu \mathrm{l}$ of streptavidin-phycoerythrin for $30 \mathrm{~min}$ (both steps performed in the dark). After a final wash, the wells were resuspended in $100 \mu \mathrm{l}$ of assay buffer. The reactions were detected following the addition of streptavidin-phycoerythrin (Milliplex ${ }^{\circledR}$; Merck KGaA) using the XPONENT software analysis system (version 3.1; Luminex Corporation). The concentrations of tissue cytokines and chemokines were calculated from the standard curves of known concentrations of recombinant mouse cytokines and chemokines.

Evaluation of tear film and ocular surface parameters. The tear volume was measured using phenol red-impregnated cotton threads (Zone-Quick Thread Tear Test; Oasis Medical) as previously described (28). The thread was placed on the lower conjunctival fornix at approximately one-third of the lower eyelid distance from the lateral canthus for $20 \mathrm{sec}$. The length of the wet red thread was measured in $\mathrm{mm}$ under a photomicroscope (light microscope; magnification, $\mathrm{x1}$; SMZ 1500; Nikon Corporation). A standard curve was derived to convert distance into volume based on the known uptake volume of basic stock solution (1,500 $\mathrm{ml} 0.9 \%$ saline combined with $5 \mathrm{ml} 5 \mathrm{M} \mathrm{NaOH}$ ) over a $20 \mathrm{sec}$ period.

TBUT and CFSS measurements were conducted as previously described (31). Sodium instilling was performed with $1 \mu 1$ $1 \%$ sodium fluorescein into the inferior conjunctival sac using a micropipette. After three blinks, the TBUT was recorded in seconds using slit-lamp biomicroscopy (magnification, $\mathrm{x} 16$; BQ-900; Haag-Streit) under cobalt blue light. After a total of 90 seconds, punctate staining of the corneal surface was evaluated by a researcher who was blinded to the therapeutic conditions. For CFSS, each cornea was divided into four quadrants that were individually scored. The intensity of corneal fluorescein staining was calculated using a 4-point scale (0-4) based on a previous study (29), as follows: 0, absent; 1 , slight punctate staining, $<30$ spots; 2 , punctate staining $>30$ spots, but non-diffuse; 3 , diffuse staining but no positive plaque; and 
A

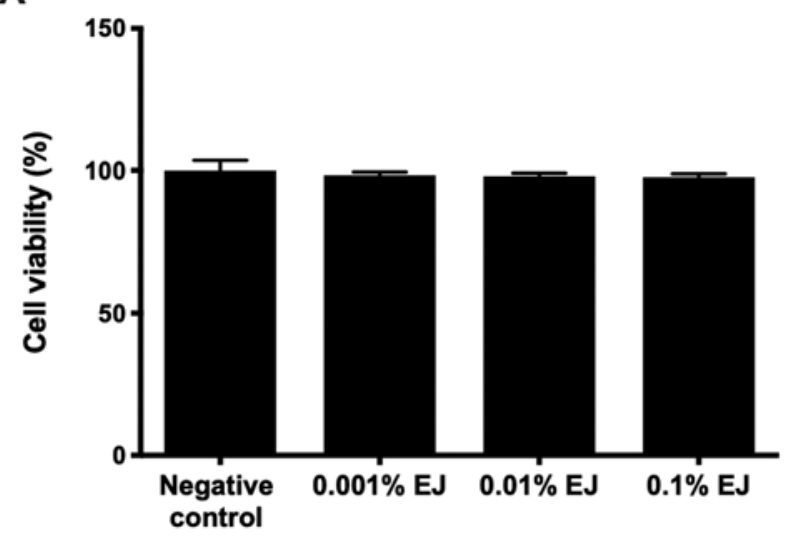

B

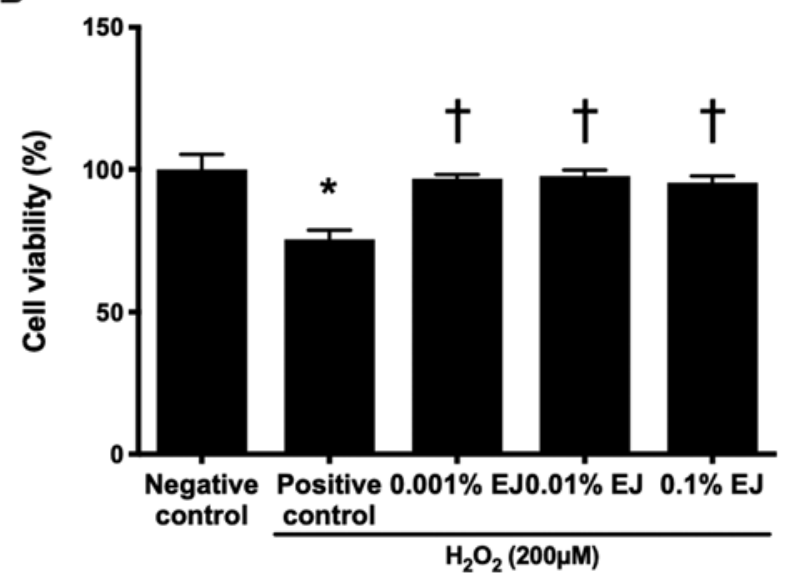

Figure 1. Effect of pretreatment with EJ extracts on the viability of HCE cells. (A) The effect of EJ extracts on the viability of HCE cells. (B) The effect of EJ extracts on HCE cells with or without exposed to $200 \mu \mathrm{M} \mathrm{H}_{2} \mathrm{O}_{2}$. The results are presented as percentages relative to the negative control. " $\mathrm{P}<0.01$ vs. negative control and $\mathrm{P}<0.01$ vs. positive control. EJ, Eurya japonica; HCE, human corneal epithelium; $\mathrm{H}_{2} \mathrm{O}_{2}$, hydrogen peroxide. Negative control, treatment without either EJ extracts or $\mathrm{H}_{2} \mathrm{O}_{2}$; Positive control, only treatment with $\mathrm{H}_{2} \mathrm{O}_{2}$.
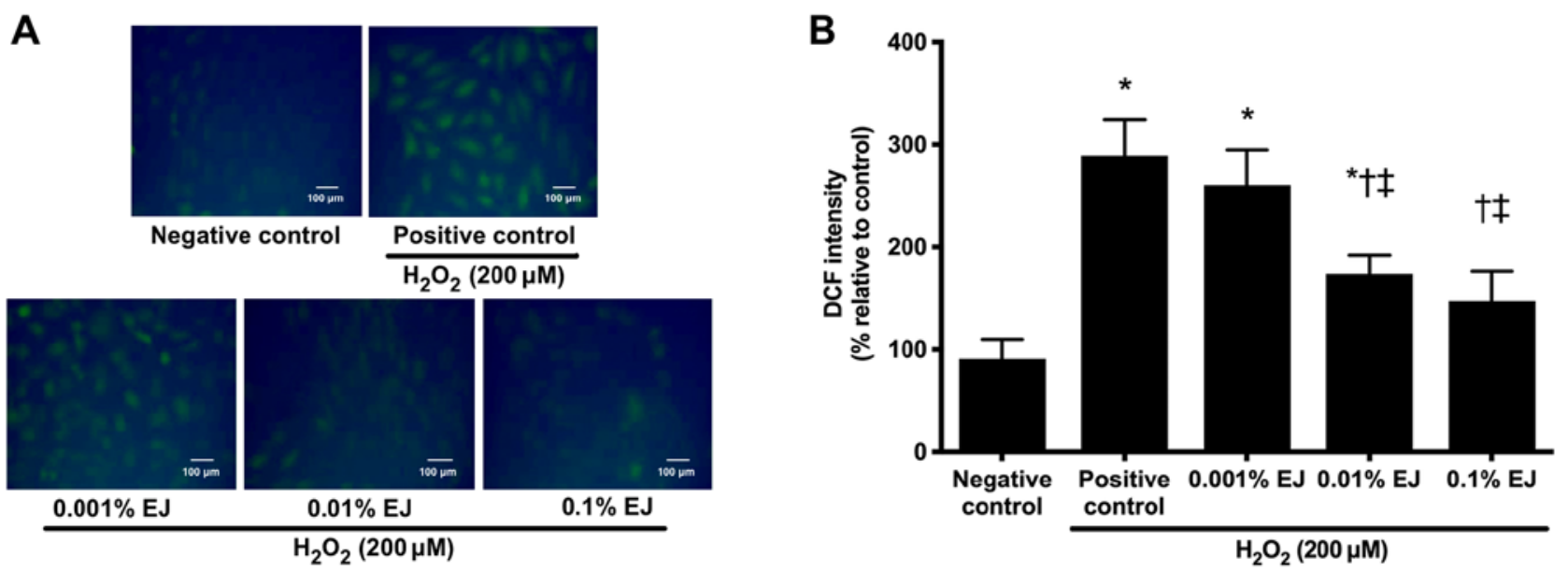

Figure 2. DCF staining and subsequent confocal fluorescence microscopy findings of $200 \mu \mathrm{M} \mathrm{H}_{2} \mathrm{O}_{2}$-treated human corneal epithelial cells with or without pretreatment with EJ extracts. (A) Representative microscopy images of DCF staining and (B) Relative fluorescence intensity results. Data are expressed as the percentage normalized to the negative control. ${ }^{*} \mathrm{P}<0.05$ vs. negative control; ${ }^{\dagger} \mathrm{P}<0.05$ vs. positive control and ${ }^{\dagger} \mathrm{P}<0.05$ vs. the $0.001 \%$ EJ group. EJ, Eurya japonica; DCF, dichlorodihydrofluorescein diacetate; $\mathrm{H}_{2} \mathrm{O}_{2}$, hydrogen peroxide.

4, positive fluorescein plaque. Total scores collected from the four quadrants, respectively, were added to generate a final grade; the maximum possible score was 16 points.

Statistical analysis. Data are presented as the mean \pm standard deviation. SPSS 18.0 (SPSS, Inc.) was used for analysis. The Kruskal-Wallis test with Bonferroni post hoc analysis was used to compare cell viability, cytokine and chemokine levels and DCF-DA value between the groups. Normal distribution of the data was verified using the Kolmogorov-Smirnov test. Statistical differences in tear volume, TBUT and corneal fluorescein staining among the groups were determined using one-way ANOVA followed by Dunnett's post hoc test. Sphericity assumptions were evaluated with Mauchly's test, and in the case of violation, the data were adjusted with an Epsilon Greenhouse-Geisser statistic. $\mathrm{P}<0.05$ was considered to indicate a statistically significant difference.

\section{Results}

$\mathrm{H}_{2} \mathrm{O}_{2}$-induce scytotoxicity in $\mathrm{HCE}$ cells. No statistically significant difference was indicated on the viability of HCE cells between the $0.001,0.01$ and $0.1 \%$ EJ extract groups compared with the positive control (Fig. 1A). The positive control exhibited a significant decrease in HCE cell viability compared with the negative control $(75.33 \pm 3.22 \%$; $\mathrm{P}<0.01$; Fig. 1B). The viability of HCE cells pretreated with EJ extracts were $96.67 \pm 1.53 \%$ in the $0.001 \%$ EJ group, $97.67 \pm 2.08 \%$ in the $0.01 \%$ EJ group and $95.33 \pm 2.31 \%$ in the $0.1 \%$ EJ group (all $\mathrm{P}<0.01$ vs. the positive control; Fig 1B).

ROS levels in HCE cells. A significant increase in DCF-DA fluorescence was observed in HCE cells following exposure to $200 \mu \mathrm{M} \mathrm{H}_{2} \mathrm{O}_{2}(\mathrm{P}<0.01$ vs. negative control). Pre-treatment with 0.01 and $0.1 \%$ EJ extracts significantly reduced DCF-DA fluorescence intensity in a concentration-dependent manner 

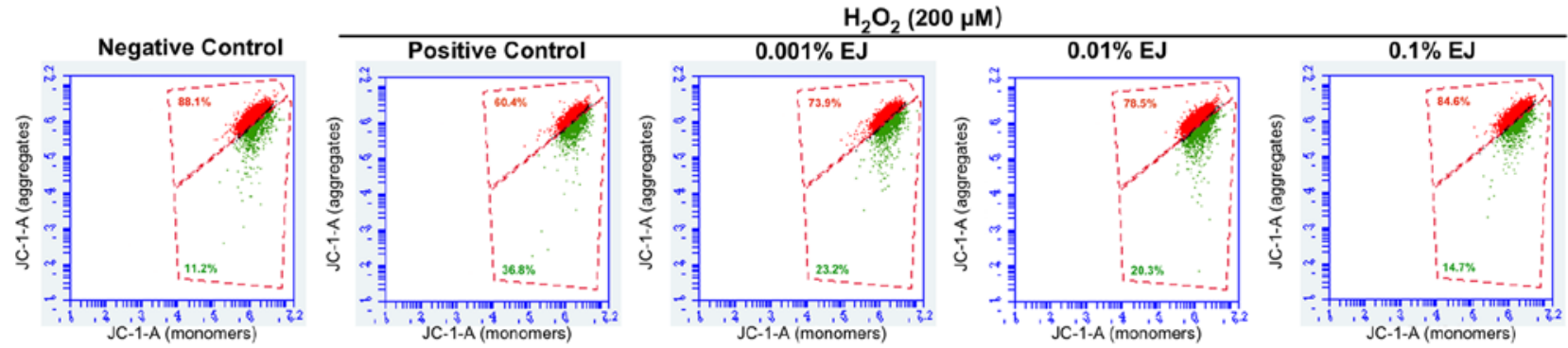

Figure 3. Representative flow cytometry results showing recovery of $\mathrm{H}_{2} \mathrm{O}_{2}$-induced impairment of mitochondrial membrane potential through treatment with EJ extracts. EJ, Eurya japonica; $\mathrm{H}_{2} \mathrm{O}_{2}$, hydrogen peroxide; JC-1, 5,5',6,6'-tetrachloro-1,1',3,3'-tetraethyl benzimidazolylcarbocyanine iodide.

Table I. Percentage of red fluorescence in the negative control and hydrogen peroxide-treated cells with or without EJ extract pretreatment.

\begin{tabular}{lc}
\hline Groups & Red fluorescence $(\%)$ \\
\hline Negative control & $89.47 \pm 5.79$ \\
Positive control & $57.27 \pm 7.51^{\mathrm{a}}$ \\
$0.001 \%$ EJ & $72.67 \pm 2.67^{\mathrm{a}, \mathrm{b}}$ \\
$0.01 \%$ EJ & $81.83 \pm 3.45^{\mathrm{b}}$ \\
$0.1 \%$ EJ & $87.83 \pm 2.93^{\mathrm{b}, \mathrm{c}}$ \\
\hline
\end{tabular}

Data are expressed as the mean \pm standard deviation. ${ }^{\mathrm{a}} \mathrm{P}<0.05$ vs. negative control; ${ }^{b} \mathrm{P}<0.05$ vs. positive control and ${ }^{\mathrm{c}} \mathrm{P}<0.05$ vs. $0.001 \%$ EJ. EJ, Eurya japonica.

(0.001\% EJ, P=0.9 vs. positive control; $0.01 \% \mathrm{EJ}$ and $0.1 \% \mathrm{EJ}$, $\mathrm{P}<0.05$ vs. positive control or $0.001 \%$ EJ; Fig. 2).

Mitochondrial membrane potential in HCE cells. In the mitochondrial membrane potential assay, $\mathrm{H}_{2} \mathrm{O}_{2}$-treated $\mathrm{HCE}$ cells demonstrated a significant decrease in red fluorescent signal compared with the negative control $(\mathrm{P}<0.01)$. Compared with the $\mathrm{H}_{2} \mathrm{O}_{2}$ positive control group, different concentrations of $E J$ extracts significantly increased the red fluorescence signal in a concentration-dependent manner (all $\mathrm{P}<0.05$ vs. the positive control; $0.1 \%$ EJ, $\mathrm{P}=0.03$ vs. $0.001 \% \mathrm{EJ})$. Compared with the negative control group, there was no significant difference in the proportion of red fluorescence between the $0.01 \%$ and $0.1 \%$ EJ groups (Fig. 3; Table I).

ROS levels in conjunctival tissues. In the DCF-DA assay, treatment with 0.01 and $0.1 \%$ EJ extracts resulted in a significant decrease in ROS levels compared with the EDE, BSS or $0.001 \%$ EJ group (all $\mathrm{P}<0.05$ ). In addition, the $0.1 \%$ EJ group showed a significantly lower DCF-DA staining intensity compared with the $0.01 \%$ EJ group ( $\mathrm{P}=0.02$; Fig. 4).

Inflammatory cytokine and chemokine levels in conjunctival tissues. The concentrations of TNF- $\alpha$, IL-1 $1 \beta$, IP-10 and MIG in the $0.1 \%$ EJ group were significantly lower compared with the EDE, BSS, $0.001 \% \mathrm{EJ}$ and $0.01 \%$ EJ groups (all $\mathrm{P}<0.05$ ). The $0.01 \%$ EJ group also demonstrated significantly reduced TNF- $\alpha$, IL-1 $\beta$ and IP-10 levels compared with the EDE or BSS groups (all $\mathrm{P}<0.05$ ) and significantly reduced MIG levels compared with the EDE group $(\mathrm{P}=0.02)$. No significant differences were observed in the inflammatory cytokine and chemokine levels among the EDE, BSS and 0.001\% EJ groups (Fig. 5).

Clinical parameters in the tear film and ocular surface. Following a period of seven days of desiccating stress, the mean tear volumes were $0.020 \pm 0.007 \mu 1$ (EDE group), $0.023 \pm 0.007 \mu 1$ (BSS group), $0.025 \pm 0.006 \mu 1$ (0.001\% EJ group), $0.032 \pm 0.006 \mu \mathrm{l}$ (0.01\% EJ group) and $0.038 \pm 0.007 \mu \mathrm{l}$ (0.1\% EJ group). The $0.01 \%$ EJ group indicated a significant increase in tear volume compared with the EDE or BSS groups, and the $0.1 \%$ EJ group indicated a significant increase in tear volume compared with the EDE, BSS or $0.001 \%$ EJ groups (all $\mathrm{P}<0.05$; Fig. 6A).

Following a period of seven days of desiccating stress, the TBUT was demonstrated to be $1.50 \pm 0.26 \mathrm{sec}$ in the EDE group, $1.54 \pm 0.18 \mathrm{sec}$ in the BSS group, $1.61 \pm 0.17 \mathrm{sec}$ in the $0.001 \%$ EJ group, $1.88 \pm 0.19 \mathrm{sec}$ in the $0.01 \%$ EJ group and $1.96 \pm 0.26 \mathrm{sec}$ in the $0.1 \%$ EJ group. The $0.01 \% \mathrm{EJ}$ and $0.1 \%$ EJ groups had significantly increased TBUT compared with the EDE or BSS groups (all $\mathrm{P}<0.05$ ). In addition, the $0.1 \%$ EJ group exhibited a significant increase in the TBUT compared with the $0.001 \%$ EJ group ( $P<0.05$ Fig. 6B).

Following a period of seven days of EDE induction in mice, the CFSS scores were $14.80 \pm 1.03$ (EDE group), $14.20 \pm 1.48$ (BSS group), $13.30 \pm 0.64$ (0.001\% EJ group), $8.20 \pm 1.40$ ( $0.01 \%$ EJ group) and $6.50 \pm 1.96$ (0.1\% EJ group). The $0.01 \%$ EJ and $0.1 \%$ EJ groups had significantly decreased CFSS scores compared with the EDE, BSS or $0.001 \%$ EJ groups (all $\mathrm{P}<0.05$ Fig. 6C and D).

\section{Discussion}

Oxidative stress is caused by an imbalance between the anti-oxidant and the pro-oxidant system (6). When excess oxidative stress arises, the balance is shifted in favor of the pro-oxidant system (32). ROS are natural by-products of normal oxygen metabolism and participate in cell signaling and homeostasis (33). A number of studies have reported that oxidative stress serves an important role in a variety of eye diseases, including uveitis, keratitis, age-related cataracts and ocular inflammation $(32,34-36)$. Oxidative stress can damage the ocular surface via ROS production, leading to visual impairment (37).

Chronic inflammation in DE is associated with hyperosmolarity and tear film instability (38). In addition, oxidative 


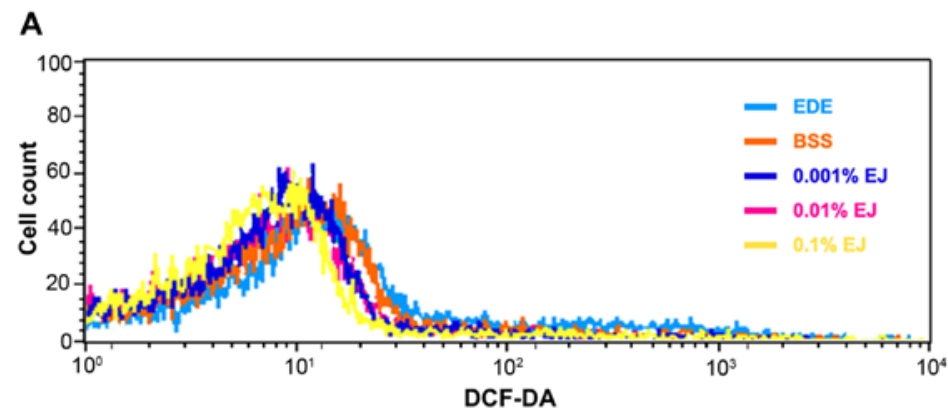

B

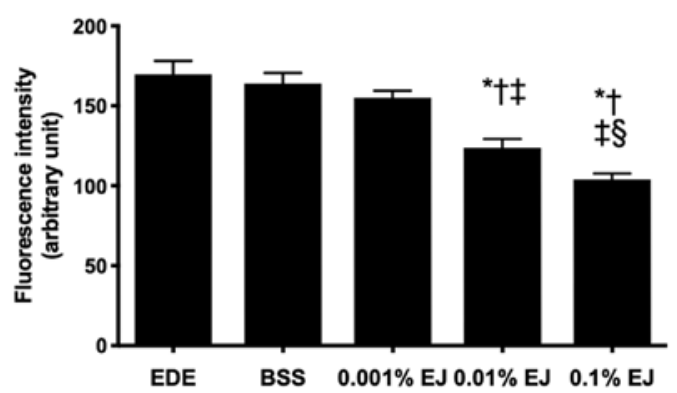

Figure 4. Levels of reactive oxygen species in the conjunctiva. DCF-DA results showing (A) representative images, and (B) fluorescence intensity in the EDE, BSS, and $0.001,0.01$ and $0.1 \%$ EJ extract groups at seven days $\left({ }^{*} \mathrm{P}<0.05\right)$. ${ }^{*} \mathrm{P}<0.05$ vs. EDE; ${ }^{\mathrm{P}} \mathrm{P}<0.05$ vs. $\mathrm{BSS} ;{ }^{\circ} \mathrm{P}<0.05$ vs. $0.001 \%$ EJ and ${ }^{\$} \mathrm{P}<0.05$ vs. $0.01 \%$ EJ. DCF-DA, dichlorodihydrofluorescein diacetate; EDE, experimental dry eye; BSS, balanced salt solution; EJ, Eurya japonica.

A

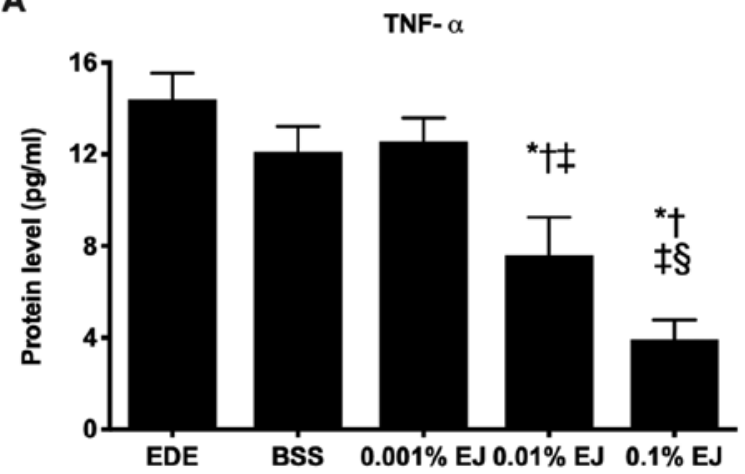

C

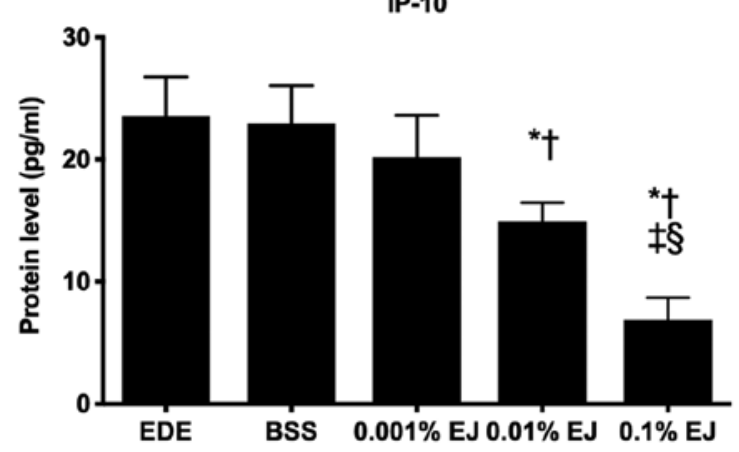

B

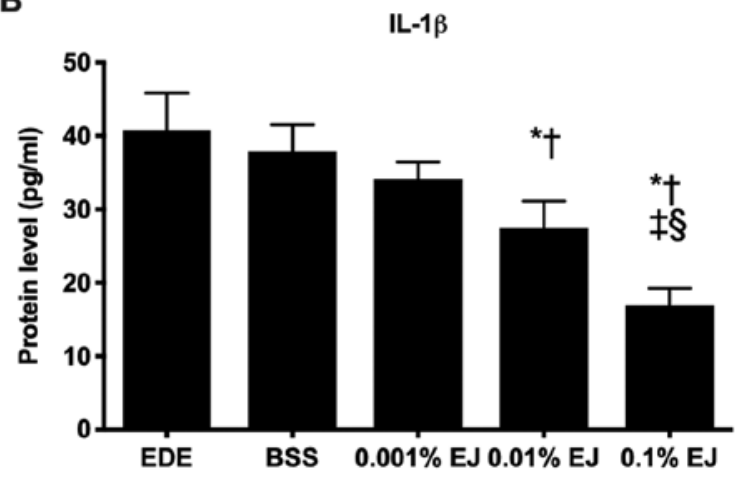

D

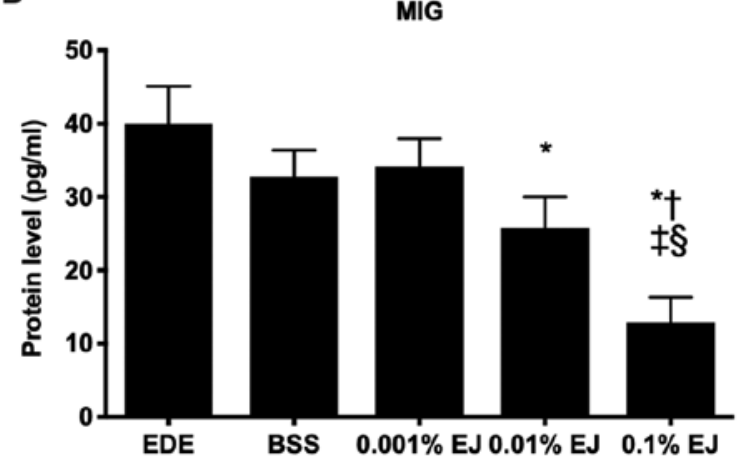

Figure 5. Levels of (A) TNF- $\alpha$, (B) IL-1 $\beta$, (C) IP-10 and (D) MIG in the conjunctivas of EDE, BSS, and $0.001,0.01$ and $0.1 \%$ EJ extract groups. ${ }^{*} \mathrm{P}<0.05$ vs. EDE; ${ }^{\dagger} \mathrm{P}<0.05$ vs. BSS; ${ }^{\dagger} \mathrm{P}<0.05$ vs. $0.001 \%$ EJ and ${ }^{\circledR} \mathrm{P}<0.05$ vs. $0.01 \%$ EJ. TNF- $\alpha$, tumor necrosis factor; IL-1 $\beta$, interleukin-1 $\beta$; IP- $10,10 \mathrm{kDa}$ interferon gamma-induced protein 10; MIG, monokine induced by interferon- $\gamma$; EDE, experimental dry eye; BSS, balanced salt solution; EJ, Eurya japonica.

stress is closely associated with DE and is involved in the initiation and progression of epithelial cell injury (39-41). Previous studies have indicated that hyperosmolarity induces oxidative stress, mitochondrial dysfunction and apoptosis in HCE cells by stimulating ROS production and disrupting the balance of oxygenases and anti-oxidant enzymes $(42,43)$. Oxidative stress may lead to inflammation and cell death in the ocular surface epithelium of murine DE $(10,13)$. Currently, a number of different therapies, including administration of cyclosporine and artificial tears, have been used to treat 
A

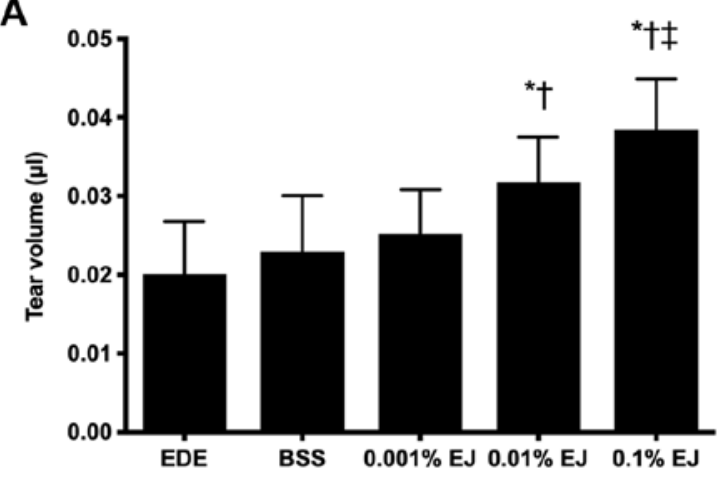

C

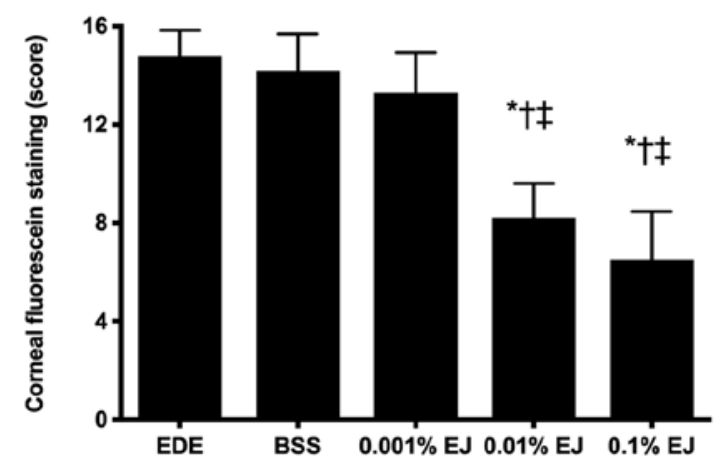

B

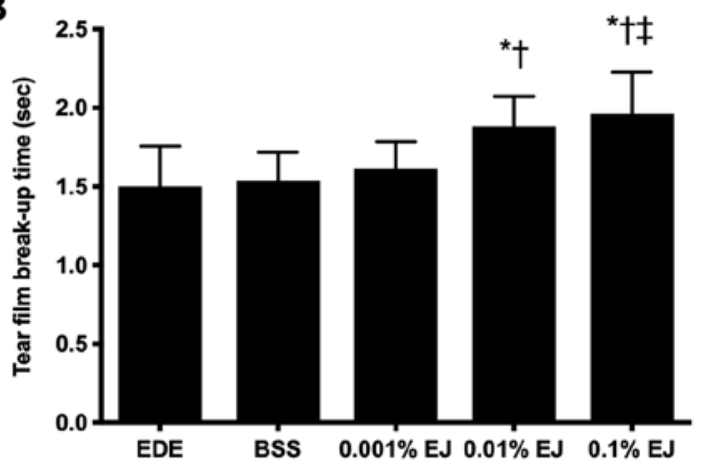

D
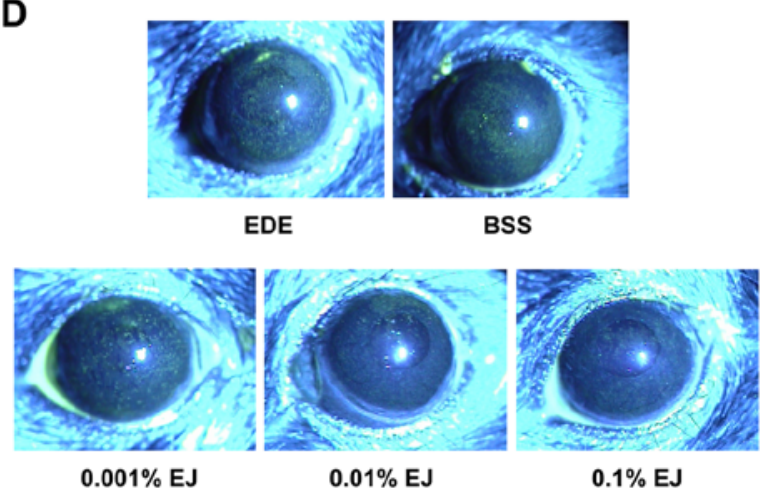

Figure 6. Mean (A) tear volume, (B) tear film break-up time, (C) corneal fluorescein staining scores and (D) representative images of EDE, BSS and 0.001, 0.01 and $0.1 \%$ EJ extract groups following seven days of desiccant stress. ${ }^{*} \mathrm{P}<0.05$ vs. EDE; ${ }^{\dagger} \mathrm{P}<0.05$ vs. BSS and ${ }^{\ddagger} \mathrm{P}<0.05$ vs. $0.001 \%$ EJ. EDE, experimental dry eye; BSS, balanced salt solution; EJ, Eurya japonica.

DE $(4,5)$. However, these agents have variable therapeutic responses and are unable to achieve complete resolution of inflammatory DE $(11,31)$. Topical or local application of anti-oxidative agents may be a novel treatment approach for DE (10-12). Among agents that have anti-inflammatory and anti-oxidant effects for the treatment of DE, the efficacy of different concentrations of EJ extracts was evaluated via topical application.

The leaves of EJ contain eutigoside B and C, which exert anti-oxidative and anti-inflammatory effects through the inhibition of pro-inflammatory cy tokines (TNF- $\alpha$ and IL-6), inducible nitric oxide synthase and cyclo-oxygenase-2 (21). Chrysoeriol isolated from Eurya ciliata protected osteoblasts from oxidative stress-induced toxicity by inhibiting $\mathrm{H}_{2} \mathrm{O}_{2}$-induced nuclear factor- $\kappa \mathrm{B}$ ligand and IL- 6 production (19).

In the present in vitro study, a variety of concentrations of EJ extracts could maintain the viability of HCE cells in the presence of $\mathrm{H}_{2} \mathrm{O}_{2}$. In addition, the DCF-DA assay and mitochondrial membrane potential measurements showed that the EJ extracts could reduce ROS production and protect mitochondrial function. These findings demonstrated that EJ extracts had anti-oxidative properties in HCE cells exposed to oxidative stress. In the present in vivo study, the levels of conjunctival intracellular ROS significantly decreased following topical instillation of EJ extracts. In addition, topically applied EJ extracts significantly decreased the expression of inflammatory cytokines and chemokines TNF- $\alpha$, IL- $1 \beta$, IP-10 and MIG in the conjunctiva. These results suggested that EJ extracts could have anti-oxidative and anti-inflammatory properties in the ocular surface following topical administration.

Previous studies have demonstrated that topical administration of anti-oxidants could decrease inflammation on the ocular surface of animal EDE (10-13). It has also been demonstrated that topical application of anti-inflammatory medicines exerted beneficial effects on tear film stability and ocular surface integrity $(44,45)$. In the present study, the effects of topical EJ extracts on a variety of clinical parameters, including the tear volume, TBUT and CFSS scores were investigated using a mouse model of EDE. Despite continuous exposure to desiccating stress and anticholinergic treatment, $0.01 \%$ and $0.1 \%$ EJ extract-treated eyes showed an increase in tear production, improvement in TBUT and reversal of corneal epithelial damage as determined by the decrease in corneal fluorescein uptake. The present study demonstrated that the anti-oxidative and anti-inflammatory properties of EJ extracts exibit a beneficial effect on the improvement of various tear film and ocular surface parameters.

Collectively, EJ extracts protected the ocular surface of epithelial cells against oxidative stress by inhibiting ROS production. In addition, topical EJ extract application could reduce the production of ROS and expression of inflammatory molecules in the ocular surface, thereby improving the clinical signs of murine DE. Therefore, topical EJ extract application could ameliorate DE in terms of its oxidative, inflammatory and clinical characteristics. Moreover, EJ extracts may exhibit potential as therapeutic agents for the treatment of DE. 


\section{Acknowledgements}

Not applicable.

\section{Funding}

The current study was supported by the Forest Science \& Technology Projects (grant no. S121313L50100) of the Korean Forest Service and the CNUH Biomedical Research Institute (grant nos. CRI 18093-1 and BCRI 20072)

\section{Availability of data and materials}

The datasets used and/or analyzed during the current study are available from the corresponding author on reasonable request.

\section{Authors' contributions}

KCY designed the experiment and revised the manuscript. LL, RJ, YL, and YSJ performed the experiments. LL, LY, WC, JHN and HJY analyzed and interpreted the data. LL and WC drafted the manuscript. All authors read and approved the final manuscript and agree to be accountable for all aspects of the research in ensuring that the accuracy or integrity of any part of the work are appropriately investigated and resolved.

\section{Ethics approval and consent to participate}

This research protocol was approved by the Chonnam National University Medical School Research Institutional Animal Care and Use Committee. Maintenance of animals and all in vivo experiments were performed in accordance with the Association for Research in Vision and Ophthalmology statement for the Use of Animals in Ophthalmic and Vision Research.

\section{Patient consent for publication}

Not applicable.

\section{Competing interests}

The authors declare that they have no competing interests.

\section{References}

1. No authors listed: The definition and classification of dry eye disease: Report of the definition and classification subcommittee of the international dry eye workshop (2007). Ocul Surf 5: 75-92, 2007.

2. Paulsen AJ, Cruickshanks KJ, Fischer ME, Huang GH, Klein BE, Klein R and Dalton DS: Dry eye in the beaver dam offspring study: Prevalence, risk factors, and health-related quality of life. Am J Ophthalmol 157: 799-806, 2014.

3. Gayton JL: Etiology, prevalence, and treatment of dry eye disease. Clin Ophthalmol 3: 405-412, 2009.

4. Wan KH, Chen LJ and Young AL: Efficacy and safety of topical $0.05 \%$ cyclosporine eye drops in the treatment of dry eye syndrome: A systematic review and meta-analysis. Ocul Surf 13: 213-225, 2015.

5. You IC, Li Y, Jin R, Ahn M, Choi W and Yoon KC: Comparison of $0.1 \%, 0.18 \%$, and $0.3 \%$ hyaluronic acid eye drops in the treatment of experimental dry eye. J Ocul Pharmacol Ther 34 $557-564,2018$.

6. Wakamatsu TH, Dogru M and Tsubota K: Tearful relations: Oxidative stress, inflammation and eye diseases. Arq Bras Oftalmol 71: 72-79, 2008.
7. Uchino Y, Kawakita T, Miyazawa M, Ishii T, Onouchi H, Yasuda K, Ogawa Y, Shimmura S, Ishii N and Tsubota K: Oxidative stress induced inflammation initiates functional decline of tear production. PLoS One 7: e45805, 2012.

8. Shoham A, Hadziahmetovic M, Dunaief JL, Mydlarski MB and Schipper HM: Oxidative stress in diseases of the human cornea. Free Radic Biol Med 45: 1047-1055, 2008.

9. Yin Y, Zong R, Bao X, Zheng X, Cui H, Liu Z and Zhou Y: Oxidative stress suppresses cellular autophagy in corneal epithelium. Invest Ophthalmol Vis Sci 59: 3286-3293, 2018.

10. Choi W, Lee JB, Cui L, Li Y, Li Z, Choi JS, Lee HS and Yoon KC: Therapeutic efficacy of topically applied antioxidant medicinal plant extracts in a mouse model of experimental dry eye. Oxid Med Cell Longev 2016: 4727415, 2016.

11. Lee HS, Choi JH, Cui L, Li Y, Yang JM, Yun JJ, Jung JE, Choi $\mathrm{W}$ and Yoon KC: Anti-inflammatory and antioxidative effects of Camellia japonica on human corneal epithelial cells and experimental dry eye: in vivo and in vitro study. Invest Ophthalmol Vis Sci 58: 1196-1207, 2017.

12. Cui L, Lee HS, Li Y, Choi JH, Yun JJ, Jung JE, Choi W and Yoon KC: Experimental and clinical applications of Chamaecyparis obtusa extracts in dry eye disease. Oxid Med Cell Longev 2017: 4523673, 2017.

13. Choi W, Kim JC, Kim WS, Oh HJ, Yang JM, Lee JB and Yoon KC: Clinical effect of antioxidant glasses containing extracts of medicinal plants in patients with dry eye disease: A multi-center, prospective, randomized, double-blind, placebo-controlled trial. PLoS One 10: e0139761, 2015.

14. Park SY, Yang HC, Moon JY, Lee NH, Kim SJ, Kang JH, Lee YK, Park DB, Yoo ES and Kang HK: Induction of the apoptosis of HL-60 promyelocytic leukemia cells by Eurya emarginata. Cancer Lett 205: 31-38, 2004.

15. Chung MG and Epperson BK: Clonal and spatial genetic structure in Eurya emarginata (Theaceae). Heredity (Edinb) 84 (Pt 2): 170-177, 2000.

16. Park SY, Yang HC, Moon JY, Lee NH, Kim SJ, Kang JH, Lee YK, Park DB, Yoo ES and Kang HK: The cytotoxicity of eutigosides from Eurya emarginata against HL-60 promyelocytic leukemia cells. Arch Pharm Res 28: 1047-1052, 2005.

17. Seo EJ, Kuete V, Kadioglu O, Krusche B, Schröder S, Greten HJ, Arend J, Lee IS and Efferth T: Antiangiogenic activity and pharmacogenomics of medicinal plants from traditional korean medicine. Evid Based Complement Alternat Med 2013: 131306, 2013.

18. Yang Kuo LM, Zhang LJ, Huang HT, Lin ZH, Liaw CC, Cheng HL, Lee KH, Morris Natschke SL, Kuo YH and Ho HO: Antioxidant lignans and chromone glycosides from Eurya japonica. J Nat Prod 76: 580-587, 2013.

19. Kim YH, Lee YS and Choi EM: Chrysoeriol isolated from Eurya cilliata leaves protects MC3T3-E1 cells against hydrogen peroxide-induced inhibition of osteoblastic differentiation. J Appl Toxicol 30: 666-673, 2010.

20. Lee HJ, Oh TH, Yoon WJ, Kang GJ, Yang EJ, Park SS, Lee NH, Kang HK and Yoo ES: Eutigoside C inhibits the production of inflammatory mediators (NO, PGE (2), IL-6) by down-regulating NF-kappaB and MAP kinase activity in LPS-stimulated RAW 264.7 cells. J Pharm Pharmacol 60: 917-924, 2008.

21. Park SY, Lee HJ, Yoon WJ, Kang GJ, Moon JY, Lee NH, Kim SJ, Kang HK and Yoo ES: Inhibitory effects of eutigosides isolated from Eurya emarginata on the inflammatory mediators in RAW264.7 cells. Arch Pharm Res 28: 1244-1250, 2005.

22. Kim C, Lee IH, Hyun HB, Kim JC, Gyawali R, Lee SG, Lee J, Kim SH, Shim BS, Cho SK, et al: Supercritical fluid extraction of citrus iyo hort. ex tanaka pericarp inhibits growth and induces apoptosis through abrogation of STAT3 regulated gene products in human prostate cancer xenograft mouse model. Integr Cancer Ther 16: 227-243, 2017.

23. Sookwong P, Suttiarporn P, Boontakham P, Seekhow P, Wangtueai $S$ and Mahatheeranont S: Simultaneous quantification of vitamin E, $\gamma$-oryzanols and xanthophylls from rice bran essences extracted by supercritical CO2. Food Chem 211: 140-147, 2016.

24. Kim H, Roh HS, Kim JE, Park SD, Park WH and Moon JY: Compound $\mathrm{K}$ attenuates stromal cell-derived growth factor 1 (SDF-1)-induced migration of C6 glioma cells. Nutr Res Pract 10: 259-264, 2016.

25. Kopalli SR, Cha KM, Jeong MS, Lee SH, Sung JH, Seo SK and Kim SK: Pectinase-treated Panax ginseng ameliorates hydrogen peroxide-induced oxidative stress in GC-2 sperm cells and modulates testicular gene expression in aged rats. J Ginseng Res 40: 185-195, 2016. 
26. Dalal S, Zha Q, Singh M and Singh K: Osteopontin-stimulated apoptosis in cardiac myocytes involves oxidative stress and mitochondrial death pathway: Role of a pro-apoptotic protein BIK. Mol Cell Biochem 418: 1-11, 2016.

27. Yoon KC, De Paiva CS, Qi H, Chen Z, Farley WJ, Li DQ, Stern ME and Pflugfelder SC: Desiccating environmental stress exacerbates autoimmune lacrimal keratoconjunctivitis in non-obese diabetic mice. J Autoimmun 30: 212-221, 2008.

28. Yoon KC, Ahn KY, Choi W, Li Z, Choi JS, Lee SH and Park SH: Tear production and ocular surface changes in experimental dry eye after elimination of desiccating stress. Invest Ophthalmol Vis Sci 52: 7267-7273, 2011.

29. Pauly A, Brignole-Baudouin F, Labbė A, Liang H, Warnet JM and Baudouin C: New tools for the evaluation of toxic ocular surface changes in the rat. Invest Ophthalmol Vis Sci 48: 5473-5483, 2007.

30. Oh HJ, Li Z, Park SH and Yoon KC: Effect of hypotonic $0.18 \%$ sodium hyaluronate eyedrops on inflammation of the ocular surface in experimental dry eye. J Ocul Pharmacol Ther 30: 533-542, 2014.

31. Sung MS, Li Z, Cui L, Choi JS, Choi W, Park MJ, Park SH and Yoon KC: Effect of topical 5-Aminoimidazole-4-carboxamide-1 - $\beta$-d-ribofuranoside in a mouse model of experimental dry eye. Invest Ophthalmol Vis Sci 56: 3149-3158, 2015.

32. Dogru M, Kojima T, Simsek C and Tsubota K: Potential role of oxidative stress in ocular surface inflammation and dry eye disease. Invest Ophthalmol Vis Sci 59: DES163-DES168, 2018.

33. Devasagayam TP, Tilak JC, Boloor KK, Sane KS, Ghaskadbi SS and Lele RD: Free radicals and antioxidants in human health: Current status and future prospects. J Assoc Physicians India 52: 794-804, 2004

34. Alió JL, Artola A, Serra A, Ayala MJ and Mulet ME: Effect of topical antioxidant therapy on experimental infectious keratitis. Cornea 14: 175-179, 1995

35. Gritz DC, Montes C, Atalla LR, Wu GS, Sevanian A and Rao NA Histochemical localization of superoxide production in experimental autoimmune uveitis. Curr Eye Res 10: 927-931, 1991.

36. Erol Tinaztepe Ö, Ay M and Eser E: Nuclear and mitochondrial DNA of age-related cataract patients are susceptible to oxidative damage. Curr Eye Res 42: 583-588, 2017.
37. Pinazo Durán MD, Gallego Pinazo R, García Medina JJ, Zanon Moreno V, Nucci C, Dolz Marco R, Martínez Castillo S, Galbis Estrada C, Marco Ramírez C, López-Gálvez MI, et al: Oxidative stress and its downstream signaling in aging eyes. Clin Interv Aging 9: 637-652, 2014.

38. Craig JP, Nichols KK, Akpek EK, Caffery B, Dua HS, Joo CK, Liu Z, Nelson JD, Nichols JJ, Tsubota K, et al: TFOS DEWS II definition and classification report. Ocul Surf 15: 276-283, 2017.

39. Nakamura S, Shibuya M, Nakashima H, Hisamura R, Masuda N, Imagawa $T$, Uehara $M$ and Tsubota $K$ : Involvement of oxidative stress on corneal epithelial alterations in a blink-suppressed dry eye. Invest Ophthalmol Vis Sci 48: 1552-1558, 2007.

40. Uchino Y, Kawakita T, Ishii T, Ishii N and Tsubota K: A new mouse model of dry eye disease: Oxidative stress affects functional decline in the lacrimal gland. Cornea 31 (Suppl 1): S63-S67, 2012.

41. Wakamatsu TH, Dogru M, Matsumoto Y, Kojima T, Kaido M, Ibrahim OM, Sato EA, Igarashi A, Ichihashi Y, Satake Y, et al: Evaluation of lipid oxidative stress status in Sjögren syndrome patients. Invest Ophthalmol Vis Sci 54: 201-210, 2013.

42. Li Y, Liu H, Zeng W and Wei J: Edaravone protects against hyperosmolarity-induced oxidative stress and apoptosis in primary human corneal epithelial cells. PLoS One 12: e0174437, 2017.

43. Deng R, Hua X, Li J, Chi W, Zhang Z, Lu F, Zhang L, Pflugfelder SC and Li DQ: Oxidative stress markers induced by hyperosmolarity in primary human corneal epithelial cells. PLoS One 10: e0126561, 2015.

44. Lee HS, Jang JY, Lee SH, Im SK and Yoon KC: Clinical effectiveness of topical cyclosporine a $0.05 \%$ after laser epithelial keratomileusis. Cornea 32: e150-e155, 2013.

45. Holland EJ, Darvish M, Nichols KK, Jones L and Karpecki PM: Efficacy of topical ophthalmic drugs in the treatment of dry eye disease: A systematic literature review. Ocul Surf 17: 412-423, 2019.

This work is licensed under a Creative Commons Attribution-NonCommercial-NoDerivatives 4.0 International (CC BY-NC-ND 4.0) License. 